\title{
The Relationship of Scenario Quality With the Effectiveness of Seven Jumps Problem-Based Learning Discussion on Medical Students of Mulawarman University
}

\author{
Gusti Ferri Sandaria ${ }^{\mathbf{1}}$, Sulistiawati ${ }^{\mathbf{2}}$, and Cicih Bhakti Purnamasari ${ }^{2}$ \\ ${ }^{1}$ Undergraduate Program in Medicine, Faculty of Medicine, Mulawarman University, Indonesia \\ ${ }^{2}$ Departement of Medical Education, Faculty of Medicine, Mulawarman University, Indonesia \\ *E-mail : gustiferrikpv@gmail.com
}

\begin{abstract}
Problem-based learning is a learning method which applies scenario arranged thoroughly according to specific themes and performed through group discussion. The effectiveness of problembased learning determines the success of students' learning. This study aims to find the relationship between scenario quality and the effectiveness of problem-based learning seven jumps discussion among medical students of Mulawarman University. This observational analytic study applied cross sectional approach. The respondents of this study were medical students of Mulawarman University which were selected through simple random sampling technique. The data analysis methods were descriptive data analysis and analytic data analysis using Pearson test. There were 202 respondents fulfilling both inclusive and exclusive criteria with $18-22$ age range. The male respondents were $50(24.8 \%)$ and the female respondents were $152(75.2 \%)$. Each respondent filled in questionnaires twice to evaluate different scenario. A total of 404 data were obtained from 202 respondents. The finding revealed that there was a correlation between scenario quality and problem-based learning seven jumps discussion with $\mathrm{p}$ value $=$ 0.000. In conclusion, scenario quality had a relationship with the effectiveness of problem-based learning seven jumps discussion among medical students of Mulawarman University.
\end{abstract}

Keywords: Problem-Based Learning, Scenario Quality, The Effectiveness of Discussions

\section{Introduction}

Problem-based learning (PBL) is a learning method oriented toward real-life problems that aim to improve critical and analytical thinking (Arends \& Kilcher, 2010). It uses a patient's problems as a material for the students to obtain knowledge on basic and clinical science (Konsil Kedokteran Indonesia, 2012). A discussion is an implementation of the PBL method, which is important to achieve doctor's competency in Indonesia (Mewo et al., 2018). This activity is conducted in a small group of people comprising of students and a tutor as a facilitator. The students will discuss a problem written in a scenario. This activity encourages students to be active and improve their problem-solving ability (Swanwick, 2013). To achieve successful learning, the effectiveness of the discussion must be ensured (Akbar \& Widjaja, 2019).

There are three main aspects to be considered in a PBL discussion, including scenario, students, and tutor (Pioh et al., 2016). The scenario is important in the PBL method (Irgananda \& Widodorini, 2017). It acts as a trigger so that the students are motivated to look for explanations for various phenomena in it and to find the correlation between those phenomena (Aryanty et al., 2013). A quality scenario facilitates the students to understand a case that will affect discussion effectivity (Sianipar et al., 2016). 
Several studies that compare scenario quality and PBL discussion, there was a study indicated a significant effect between scenario quality and the effectivity of PBL discussion in the School of Medicine, in which the better the scenario given to the students, the more effective the PBL discussion (Irgananda \& Widodorini, 2017; Susanti et al., 2017). However, there was another study provided a contrast result, whereas the scenario was not correlated to the discussion process (Hamidy \& Asni, 2017). Therefore, this study was conducted to investigate the correlation between scenario quality and the effectiveness of problem-based learning seven jumps discussion in medicine students of Mulawarman University.

\section{Material and Methods}

This was an observational analytic study with a cross-sectional method conducted at school of medicine of Mulawarman University from April to Mei 2021. This study is ethically approved (34/KEPK-FK/IV/2021). The sample of this study was active students who took part in the PBL seven jumps discussion in the even semesters of the 2020/2021 academic year from the class of 2018 to 2020 medical study program, and filled out a complete questionnaire. This research used simple random sampling. This study uses primary data obtained from Evaluate the Quality of PBL questionnaires that has been modified by Mewo et al. (2018) and the Tutorial Group Effectiveness Instrument (TGEI) developed by Singaram et al. (2010). The Indonesian version of the TGEI questionnaire has been tested for validity and reliability by Mewo et al. (2011). Questionnaires were distributed in the google forms to students who were selected as respondents. Data processing was carried out by using Microsoft Word 2016 software, Microsoft Excel 2016, and IBM SPSS 22.

\section{Results and Discussion}

There were six scenarios, that comprised two scenarios for three batches. The participants filled up questionnaires twice for two scenarios according to their batch. The total number of participants in this study was 202 people. Therefore, the total number of filled questionnaires was 404. The following Table 1 depicts the characteristics of participants.

Table 1. Characteristics of Respondents by Age and Gender

\begin{tabular}{ccc}
\hline Characteristics & n & Percentage (\%) \\
\hline Age (years old) & & \\
18 & 39 & 19,3 \\
19 & 74 & 36,6 \\
20 & 59 & 29,2 \\
21 & 26 & 12,9 \\
22 & 4 & 2 \\
Gender & & \\
Male & 50 & 24,8 \\
Female & 152 & 75,2 \\
\hline
\end{tabular}


Based on the data, the age of all participants was within 18-22 years old, mostly at 19 years old $(36.6 \%)$. Gender-wise, $75.2 \%$ of the participants were female.

Table 2. Analysis of The Quality of Scenario with The Effectiveness of PBL Discussion

\begin{tabular}{|c|c|c|c|c|c|c|c|c|}
\hline \multirow{4}{*}{ Variable } & \multirow{4}{*}{ Category } & \multicolumn{4}{|c|}{ Effectiveness of PBL } & \multirow{3}{*}{\multicolumn{2}{|c|}{ Total }} & \multirow{4}{*}{$\mathbf{p}$} \\
\hline & & & Dis & Issic & & & & \\
\hline & & \multicolumn{2}{|c|}{ Effective } & \multicolumn{2}{|c|}{ Ineffective } & & & \\
\hline & & $\mathbf{n}$ & $\%$ & $\mathbf{n}$ & $\%$ & $\mathbf{N}$ & $\%$ & \\
\hline \multirow{4}{*}{$\begin{array}{l}\text { Quality of } \\
\text { Scenario }\end{array}$} & Good & 169 & 41,8 & 0 & 0,0 & 169 & 41,8 & \multirow{5}{*}{0,000} \\
\hline & Average & 142 & 35,1 & 4 & 1,0 & 146 & 36,1 & \\
\hline & Need Improvement & 58 & 14,4 & 3 & 0,7 & 61 & 15,1 & \\
\hline & Not good & 25 & 6,2 & 3 & 0,7 & 28 & 6,9 & \\
\hline Total & & 394 & 97,5 & 10 & 2,5 & 404 & 100 & \\
\hline
\end{tabular}

The results of the analysis on scenario quality can be seen in Table 2 . The results showed that many participants judged that the scenario was good $(41.8 \%)$. They thought that the scenarios given could motivate the students to use literature related to the module's learning objectives. This means that the students were motivated to learn materials according to the learning objective. One of the characteristics of a scenario is that the problem should lead toward the learning issues and be structured to achieve a quality scenario (Susanti et al., 2017; Swanwick, 2013).

Table 3. The Effectiveness of The Discussion from The Three Aspects

\begin{tabular}{ccc}
\hline Aspects & n & Percentage (\%) \\
\hline Cognition & 389 & 96,3 \\
Effective & 15 & 3,7 \\
Ineffective & & \\
Motivation & 395 & 97,8 \\
Effective & 9 & 2,2 \\
Ineffective & & \\
Demotivation & 266 & 65,8 \\
Effective & 138 & 34,2 \\
Ineffective & &
\end{tabular}

The discussion in this seven jumps PBL was considered effective (97.5\%), as seen in Table 2. This was affected by three main aspects, i.e., cognition, motivation, and demotivation. Based on Table 3, all three aspects were effective. However, compared to the cognition aspect (96.3\%), motivation (97.8\%), and demotivation (65.8\%), the demotivation aspect showed the lowest value. Demotivation provided a negative aspect toward motivation and group success. This aspect is closely related to external motivation because motivation that comes from external factors is often unstable and prone to weakness (Pioh et al., 2016). The participants thought that 
the factor that affects demotivation was several students only contribute a little to the group discussion. Previous studies showed similar results (Akbar \& Widjaja, 2019; Pioh et al., 2016). Several reasons that could cause a lack of contribution include lack of preparation, low confidence, unhealthy, poor experience, lack of interest in the discussion topic, and quiet nature of the students (Akbar \& Widjaja, 2019; Shafira \& Fitri, 2020). Lack of contribution from some members might reduce the motivation of the other members, thus reducing the effectiveness of PBL discussion (Singaram et al., 2010).

After obtaining the participants' characteristics, assessing the scenario quality and effectivity of seven jumps PBL discussion, an analysis on the correlation between scenario quality and the effectivity of seven jumps PBL discussion was conducted. The results showed that there was a significant correlation between scenario quality and the effectivity of seven jumps PBL discussion in medicine students of Mulawarman University $(p=0.000)$, as seen in Table 2. These results were supported by previous study showed that scenario quality significantly affected the effectivity of PBL discussion ( $\mathrm{p}$ < 0.05) (Sianipar et al., 2016; Susanti et al., 2017). Scenario quality supports the effectiveness of PBL discussion, whereas the better the scenario, the higher the effectivity of the PBL discussion (Mewo et al., 2011). With an interesting and challenging case design, students are more motivated to learn, work together, and be active in the discussion process to achieve an effective discussion (Sianipar et al., 2016).

\section{Conclusion}

Based on the results of the study, it can be concluded that there is relationship between the quality of the scenario and the effectiveness of the seven jumps problem-based learning discussion among medical students of Mulawarman University.

\section{Acknowledgements}

I would like to express my deep gratitude to my research supervisors, for their patient guidance, encouragement and useful critiques of this research work.

\section{Conflict of Interest}

All Authors declare no conflict of interest and agree with the content of the manuscript.

\section{References}

Akbar, R., \& Widjaja, Y. (2019). Efektivitas diskusi problem-based learning di Fakultas Kedokteran Universitas Tarumanagara. Tarumanagara Medical Journal, 2(1), 160-166. https://doi.org/10.24912/tmj.v2i1.5854

Arends, R. I., \& Kilcher, A. (2010). Teaching for student learning: Becoming an accomplished teacher (1st ed.). Routledge Taylor \& Francis Group. https://doi.org/10.4324/9780203866771 Aryanty, N., Rahayu, G. R., \& Suryadi, E. (2013). Pengalaman belajar mahasiswa terkait peran skenario dalam tutorial. Jurnal Pendidikan Kedokteran Indonesia, 2(1), 62-70.

Hamidy, M. Y., \& Asni, E. (2017). Faktor-faktor yang mempengaruhi partisipasi mahasiswa dalam proses tutorial pada metode belajar problem-based learning (PBL) di Fakultas 
Kedokteran Universitas Riau. Jurnal Ilmu Kedokteran, 4(1), 30-35. https://doi.org/10.26891/JIK.v4i1.2010.30-35

Irgananda, C. I., \& Widodorini, T. (2017). Pengaruh kualitas skenario dan peran fasilitator terhadap keefektifan diskusi kelompok problem-based learning. Erudio Journal of Educational Innovation, 4(1), 8-15. https://doi.org/10.18551/erudio.4-1.2

Konsil Kedokteran Indonesia. (2012). Standar Kompetensi Dokter Indonesia (2nd ed.). Konsil Kedokteran Indonesia.

Mewo, Y. M., Manoppo, F. P., \& Wungouw, H. I. (2018). Evaluasi kualitas skenario problembased learning di Fakultas Kedokteran Universitas Sam Ratulangi. Jurnal E-Biomedik, 6(2), 90-95. https://doi.org/10.35790/ebm.6.2.2018.20967

Mewo, Y. M., Widodo, S. O. S., \& Prihartono, J. (2011). Persepsi mahasiswa terhadap efektivitas kelompok diskusi tutorial problem-based learning di Fakultas Kedokteran Universitas Sam Ratulangi. Jurnal Perpipki, 2(1), 22-31.

Pioh, V. E., Mewo, Y., \& Berhimpon, S. (2016). Efektivitas kelompok diskusi tutorial problem based learning di Fakultas Kedokteran Universitas Sam Ratulangi. Jurnal E-Biomedik, 4(1). https://doi.org/10.35790/ebm.4.1.2016.12141

Shafira, N. N. A., \& Fitri, A. D. (2020). Penilaian keefektifan kelompok diskusi tutorial mahasiswa kedokteran Universitas Jambi menggunakan tutorial group effectiveness instrument. Jambi Medical Journal, 8(1), 85-93. https://doi.org/10.22437/jmj.v8i1.9480

Sianipar, I., Hilmanto, D., Siregar, I., Husin, F., Sutedja, E., \& Sukandar, H. (2016). Hubungan kinerja tutor dan kualitas kasus skenario terhadap keefektifan kelompok pada metode belajar problem-based learning. Jurnal Pendidikan Dan Pelayanan Kebidanan Indonesia, $3(2), 1-7$.

Singaram, V. S., Van Der Vleuten, C. P. M., Van Berkel, H., \& Dolmans, D. H. J. M. (2010). Reliability and validity of a tutorial group effectiveness instrument. Medical Teacher, 32(3), 133-137. https://doi.org/10.3109/01421590903480105

Susanti, P. F. E., Lisiswanti, R., Soleha, T. U., \& Okyafany, O. S. (2017). Hubungan kualitas skenario terhadap keefektifan diskusi problem-based learning (PBL) blok emergency pada mahasiswa Fakultas Kedokteran Universitas Lampung. Medulla, 7(4), 157-163.

Swanwick, T. (2013). Problem-based learning. In M. A. Albanese (Ed.), Understanding medical education: Evidence, theory and practice (2nd ed., pp. 37-52). A John Wiley \& Sons. 